\title{
Streptomyces sanyensis sp. nov., isolated from mangrove sediment
}

\author{
Jin-Lei Sui, ${ }^{1,2}$ Xiao-Xiong Xu, ${ }^{1}$ Zhi Qu, ${ }^{1}$ Hai-Long Wang, ${ }^{1}$ Hai-Peng Lin, ${ }^{1}$ \\ Oing-Yi Xie, ${ }^{1}$ Ji-Sheng Ruan ${ }^{1}$ and Kui Hong ${ }^{1}$
}

\author{
Correspondence \\ Kui Hong \\ k1022@163.net
}

\author{
${ }^{1}$ Lab of Tropical Microbial Resource, Hainan Province; Key Lab of Tropical Crop Biotechnology, \\ Ministry of Agriculture; Institute of Tropical Bioscience and Biotechnology, Chinese Academy of \\ Tropical Agriculture Sciences, Haikou 571101, PR China \\ ${ }^{2}$ College of Environment and Plant Protection, Hainan University, Danzhou 571737, PR China
}

\begin{abstract}
A novel strain, $219820^{\top}$, whose metabolites were found to be active against tumour cells, was isolated and characterized. The isolate belonged to the genus Streptomyces and had white to grey aerial mycelium and long chains of smooth spores in the aerial mycelium. A phylogenetic tree based on $16 \mathrm{~S}$ rRNA gene sequences showed that strain $219820^{\top}$ had highest similarity to members of the genus Streptomyces and was most closely, albeit loosely, associated with Streptomyces crystallinus NBRC $15401^{\top}$ (98.624\% similarity), Streptomyces melanogenes NBRC $12890^{\top}(98.565 \%)$ and Streptomyces noboritoensis NBRC $13065^{\top}(98.564 \%)$.

However, DNA-DNA relatedness and phenotypic data readily distinguished strain $219820^{\top}$ from these phylogenetically related type strains. It is evident from the combination of genotypic and phenotypic data that strain $219820^{\top}$ represents a novel species of the genus Streptomyces, for which the name Streptomyces sanyensis sp. nov. is proposed; the type strain is $219820^{\top}$ $\left(=\right.$ CGMCC $4.5626^{\top}=$ DSM $\left.42014^{\top}\right)$.
\end{abstract}

The genus Streptomyces, proposed by Waksman \& Henrici (1943), currently encompasses more than 500 species, the largest genus in the domain 'Bacteria' (Hain et al., 1997). Members of the family Streptomycetaceae have attracted great attention because of their ability to produce various natural products of considerable commercial value (Bérdy, 2005).

During a search for novel antibiotic producers, strain $219820^{\mathrm{T}}$, which showed activity against the human colon tumour cell line HCT-116, was isolated from a composite mangrove soil sample collected in Sanya, Hainan Province, China (Hong et al., 2009). The soil sample was heated in an oven at $120{ }^{\circ} \mathrm{C}$ for $60 \mathrm{~min}$, treated with a solution of chloramine-T (1.0\%, w/v) (Hayakawa et al., 1997) and then incubated for 20 days at $28{ }^{\circ} \mathrm{C}$ on isolation plates of glucose-aspartic acid-vitamin medium (Hayakawa et al., 1991). The purified strain was maintained on yeast extractmalt extract agar [International Streptomyces Project (ISP) medium 2] (Shirling \& Gottlieb, 1966) slants at $4{ }^{\circ} \mathrm{C}$ for short-term storage and as glycerol suspensions (20\%, v/v)

Abbreviations: DAP, diaminopimelic acid; ISP, International Streptomyces Project.

The GenBank/EMBL/DDBJ accession number for the 16S rRNA gene sequence of Streptomyces sanyensis $219820^{\top}$ is FJ261968.

A supplementary table is available with the online version of this paper. at $-20{ }^{\circ} \mathrm{C}$ for long-term preservation (Wellington \& Williams, 1978).

Morphology was observed by light (80i; Nikon) and scanning electron (FEI QUANTA) microscopy of ISP 2 agar cultures incubated at $28{ }^{\circ} \mathrm{C}$ for 15 days. Cultural characteristics were determined after 2 weeks at $28{ }^{\circ} \mathrm{C}$ using methods described by Shirling \& Gottlieb (1966). Colony colour was determined by using ISCC-NBS colour charts (Kelly, 1964). Physiological and biochemical characteristics of strain $219820^{\mathrm{T}}$ and its phylogenetically most closely related neighbours were tested together using the well-established procedures of Williams et al. (1983) and Kämpfer et al. (1991). Tolerance to temperature and $\mathrm{pH}$ was tested on plates of modified Bennett's agar (Jones, 1949) incubated for 7-14 days. $\mathrm{NaCl}$ tolerance was tested in liquid modified Bennett's medium incubated at $28{ }^{\circ} \mathrm{C}$ for 7-14 days.

Biomass for chemical and molecular systematic studies was obtained after incubation at $28{ }^{\circ} \mathrm{C}$ for 4-7 days in shake flasks (about 180 r.p.m.) of ISP 2 broth. Amino acids and sugars of whole-cell hydrolysates were analysed by TLC as described previously (Hasegawa et al., 1983; Lechevalier \& Lechevalier, 1980). Cellular fatty acids were extracted by the method of Sasser (1990) and the composition was determined by GC (Oliver \& Colwell, 1973). Menaquinones were extracted from freeze-dried biomass, purified according to Minnikin et al. (1984) and analysed 
by HPLC with an ODS-BP $\mathrm{C}_{18}$ column $(4.6 \times 250 \mathrm{~mm})$. Phospholipids were analysed by TLC using the technique described by Minnikin et al. (1984).

Genomic DNA preparation, and PCR amplification and sequencing of the $16 \mathrm{~S}$ rRNA gene, were carried out using the procedure described by Goodfellow et al. (2007). The 16S rRNA gene sequence of strain $219820^{\mathrm{T}}$ was multiply aligned with representative sequences of related streptomycetes obtained from GenBank/EMBL/DDBJ using CLUSTAL X software. The alignment was verified manually and adjusted prior to the reconstruction of a phylogenetic tree. The unrooted phylogenetic tree was generated via the neighbourjoining (Saitou \& Nei, 1987) and maximum-parsimony (Fitch, 1971) tree-making algorithms in MEGA version 4.0 (Tamura et al., 2007); evolutionary distances for the neighbour-joining algorithm were calculated with the Kimura two-parameter model (Kimura, 1980). Topologies of the resultant trees were evaluated in a bootstrap analysis (Felsenstein, 1985) based on 1000 replicates. Values for pairwise 16S rRNA gene sequence similarities among the closest strains were determined using the EzTaxon server (http://www.Eztaxon.org) (Chun et al., 2007). All positions containing gaps and missing data were eliminated from the dataset (complete deletion option). It was apparent from the initial neighbour-joining analysis, which included more than 500 related sequences of Streptomyces type strains, that isolate $219820^{\mathrm{T}}$ represented a bona fide member of the genus Streptomyces (data not shown).

Chromosomal DNA was extracted as described by Pospiech \& Neumann (1995). The DNA G + C content of strain $219820^{\mathrm{T}}$ was determined by the HPLC method (Mesbah et al., 1989). DNA-DNA relatedness studies were performed between strain $219820^{\mathrm{T}}$ and related type strains using a modified nylon membrane hybridization method based on PCR-mediated amplification. Chromosomal DNA of the strains was digested with Sau3AI and fragments of 200 bp to $2 \mathrm{~kb}$ were collected. Sau3AI-digested DNA was ligated with the appropriate linker applying T4 DNA ligase (TaKaRa) using a method modified from Wassill et al. (1998). The linker-modified target DNA was labelled using a PCR DIG Probe Synthesis kit (Roche). The unlabelled PCR products were spotted onto Hybond-N+ nylon membranes (Amersham) for hybridization. After a minimum of $1 \mathrm{~h}$ of prehybridization, hybridization was carried out overnight at $65{ }^{\circ} \mathrm{C}$ in rotating glass tubes. One hundred nanograms of denatured DNA probe labelled with digoxigenin was added to the hybridization solution. Washing was performed as follows: $2 \times 5$ min with $20 \mathrm{ml} 2 \times$ SSC, $0.1 \%$ SDS, then $2 \times 15$ min with $20 \mathrm{ml} 0.1 \times$ SSC, $0.1 \%$ SDS at $65{ }^{\circ} \mathrm{C}$. The filter was then processed with phosphatase-labelled anti-Dig antibody and signals were produced with the chromogenic substrate NBT/BCIP as described in the manufacturer's protocol (Roche). Signals were quantified densitometrically.

Strain $219820^{\mathrm{T}}$ grew well on most of the media tested (Supplementary Table S1, available in IJSEM Online). Pale yellow to dark yellowish-brown colonies that bore white to grey aerial spore mass were formed on ISP media 1, 2, 3, 4 and 6 (Shirling \& Gottlieb, 1966), modified Bennett's agar, Czapek's agar and nutrient agar (Dong \& Cai, 2001). Strain $219820^{\mathrm{T}}$ exhibited poor growth on ISP 5 and ISP 7 agar media. No diffusible pigment was detected on any of the media tested. Morphological observation of a 15-day-old culture of strain $219820^{\mathrm{T}}$ grown on ISP 2 agar revealed that both aerial and vegetative hyphae were abundant, well-developed and not fragmented. Strain $219820^{\mathrm{T}}$ showed typical characteristics of the genus Streptomyces. Spore chains were Rectiflexibiles in nature. Spores were elliptical or shaped like short rods (0.3$0.6 \times 0.7-1.1 \mu \mathrm{m}$ ). The spore surfaces were smooth (Fig. 1).

Strain $219820^{\mathrm{T}}$ was positive in tests for gelatin liquefaction, milk coagulation and peptonization, melanin production, $\mathrm{H}_{2} \mathrm{~S}$ production, urease production, catalase production, degradation of Tweens 20 and 80, growth on cellulose, and the oxidase test; it was negative for starch hydrolysis, nitrate reduction, L-tyrosine degradation, aesculin degradation and carboxymethyl-cellulose degradation (Table 1). Growth occurred at $\mathrm{pH}$ 5.0-9.0 (optimum, $\mathrm{pH}$ 7.0), at 10$40{ }^{\circ} \mathrm{C}$ (optimum, $28{ }^{\circ} \mathrm{C}$ ) and with $0-10 \%(\mathrm{w} / \mathrm{v}) \mathrm{NaCl}$ (optimum, $0 \% \mathrm{NaCl}$ ). Dextrin, glucose, mannose, maltose, glycerol, D-ribose and trehalose were utilized as sole carbon and energy sources, but L-arabinose, D-fructose, Dgalactose, myo-inositol, inulin, lactose, D-mannitol, raffinose, L-rhamnose, salicin, sucrose and D-xylose were not. L-Alanine, D-arginine, L-asparagine, glycine, L-histidine, L-serine and L-ornithine were metabolized as sole nitrogen sources, but not L-cysteine, L-hydroxyproline, L-methionine, L-phenylalanine, L-proline or L-valine.

Polar lipid analysis revealed the presence of phosphatidylethanolamine, phosphatidylinositol and phosphatidylinositol monomannoside, indicating that the phospholipid was of type II sensu Lechevalier et al. (1977). The menaquinones were MK-9 $\left(\mathrm{H}_{8}\right) \quad(58.5 \%)$, MK-9 $\left(\mathrm{H}_{6}\right)$

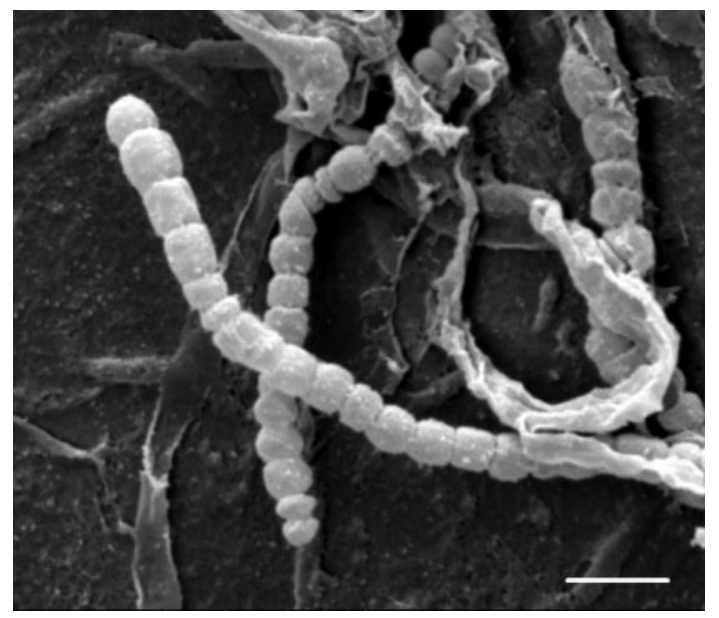

Fig. 1. Scanning electron micrograph of spore chains of strain $219820^{\top}$ grown on yeast extract-malt extract agar (ISP 2) at $28^{\circ} \mathrm{C}$ for 15 days. Bar, $2.0 \mu \mathrm{m}$. 
Table 1. Morphological and physiological characteristics of strain $219820^{\top}$ and related species of the genus Streptomyces

Taxa: 1, S. sanyensis sp. nov. $219820^{\mathrm{T}}$; 2, S. crystallinus CGMCC $4.1600^{\mathrm{T}}\left(=\mathrm{NBRC} 15401^{\mathrm{T}}\right) ; 3$, S. melanogenes CGMCC $4.1979^{\mathrm{T}}$ (=NBRC $\left.12890^{\mathrm{T}}\right)$; 4, S. noboritoensis CGMCC $4.1457^{\mathrm{T}}$ (=NBRC $\left.13065^{\mathrm{T}}\right)$. + , Positive; \pm , weakly positive; - , absent, negative; $v$, variable. All data were determined in this study.

\begin{tabular}{|c|c|c|c|c|}
\hline Characteristic & 1 & 2 & 3 & 4 \\
\hline \multicolumn{5}{|l|}{ Pigmentation on ISP 3} \\
\hline Colour of colony & Pale yellow & White & Pinkish-white & White to grey \\
\hline Reverse side of colony & Pale yellow & Dark brown & Yellow brown & Dark brown \\
\hline Growth on Czapek's agar & + & \pm & \pm & \pm \\
\hline \multicolumn{5}{|l|}{ Growth at/with: } \\
\hline $10^{\circ} \mathrm{C}$ & \pm & + & + & + \\
\hline $\mathrm{NaCl}(7 \%, \mathrm{w} / \mathrm{v})$ & + & - & - & - \\
\hline pH 5 & \pm & + & + & + \\
\hline Nitrate reduction & - & + & + & + \\
\hline Diffusible pigment & - & + & + & + \\
\hline \multicolumn{5}{|l|}{ Carbon source utilization } \\
\hline L-Arabinose & - & + & + & + \\
\hline D-Xylose & - & - & + & + \\
\hline myo-Inositol & - & - & + & $\mathrm{V}$ \\
\hline D-Mannitol & - & - & + & + \\
\hline D-Fructose & - & - & + & + \\
\hline Raffinose & - & + & + & + \\
\hline D-Galactose & - & + & + & + \\
\hline Lactose & - & + & + & + \\
\hline Mannose & + & - & + & + \\
\hline \multicolumn{5}{|l|}{ Nitrogen source utilization } \\
\hline D-Arginine & + & - & + & + \\
\hline L-Hydroxyproline & - & + & + & + \\
\hline L-Phenylalanine & - & + & + & + \\
\hline \multicolumn{5}{|l|}{ Degradation of: } \\
\hline L-Tyrosine & - & + & + & + \\
\hline CM-cellulose & - & + & + & + \\
\hline Aesculin & - & + & + & + \\
\hline Starch & - & - & + & \pm \\
\hline Gelatin & + & \pm & - & - \\
\hline
\end{tabular}

(38.9\%), MK-9 $\left(\mathrm{H}_{4}\right)(1.9 \%)$ and $\mathrm{MK}-8\left(\mathrm{H}_{4}\right)(0.7 \%)$. The major cellular fatty acids of the isolate were iso- $\mathrm{C}_{16: 0}$ $(21.86 \%)$, anteiso- $\mathrm{C}_{15: 0}(17.94 \%)$, iso- $\mathrm{C}_{15: 0}(11.04 \%)$, iso- $\mathrm{C}_{14: 0}(9.90 \%), 10$-methyl $\mathrm{C}_{16: 0}(8.39 \%), \mathrm{C}_{16: 1} \omega 9 c$ $(8.21 \%)$ and summed feature $3\left(\mathrm{C}_{16: 1} \omega 7 c\right.$ and/or iso- $\mathrm{C}_{15: 0}$ $2-\mathrm{OH} ; 5.94 \%)$. In addition, $\mathrm{C}_{17: 1} \omega 8 c(3.96 \%)$, anteiso$\mathrm{C}_{17: 0}(3.54 \%), \mathrm{C}_{17: 0}(2.38 \%)$, iso- $\mathrm{C}_{17: 0}(1.95 \%), \mathrm{C}_{15: 0}$ $(1.38 \%), \mathrm{C}_{17: 1} \omega 6 c(1.19 \%)$ and $\mathrm{C}_{19: 0}(1.02 \%)$ were detected. The $\mathrm{G}+\mathrm{C}$ content of the genomic DNA of strain $219820^{\mathrm{T}}$ was $73.24 \mathrm{~mol} \%$. These characteristics are consistent with those of the genus Streptomyces. According to Lechevalier \& Lechevalier (1980), the diagnostic amino acids of the genus Streptomyces are LL-diaminopimelic acid (DAP) and glycine, corresponding to cell-wall chemotype I. Strain $219820^{\mathrm{T}}$ contained both LL- and meso-DAP, which is similar to the type strain of the most closely related species, Streptomyces crystallinus NBRC $15401^{\mathrm{T}}$ (data from this study). Whole-cell hydrolysates of strain $219820^{\mathrm{T}}$ contained galactose and glucose.
The almost-complete 16S rRNA gene sequence (1489 nt) of strain $219820^{\mathrm{T}}$ was aligned manually with the corresponding partial 16S rRNA gene sequences of the type strains of representative members of the genus Streptomyces retrieved from GenBank/EMBL/DDBJ. Phylogenetic analyses based on 16S rRNA gene sequences showed that strain $219820^{\mathrm{T}}$ fell into a distinct subclade with the type strains of $S$. crystallinus, Streptomyces melanogenes and Streptomyces noboritoensis, an association that was supported by both of the tree-making algorithms employed. Strain $219820^{\mathrm{T}}$ shared highest $16 \mathrm{~S}$ rRNA gene sequence similarity with $S$. crystallinus NBRC $15401^{\mathrm{T}}$ (98.624\%), which corresponds to $20 \mathrm{nt}$ differences at 1489 locations with gaps, and lower values with $S$. melanogenes NBRC $12890^{\mathrm{T}}(98.565 \%)$ and $S$. noboritoensis NBRC $13065^{\mathrm{T}}(98.564 \%)$. The phylogenetic tree based on the $16 \mathrm{~S}$ rRNA gene sequences of strain $219820^{\mathrm{T}}$ and the most closely related type strains of species of the genus Streptomyces is shown in Fig. 2. 


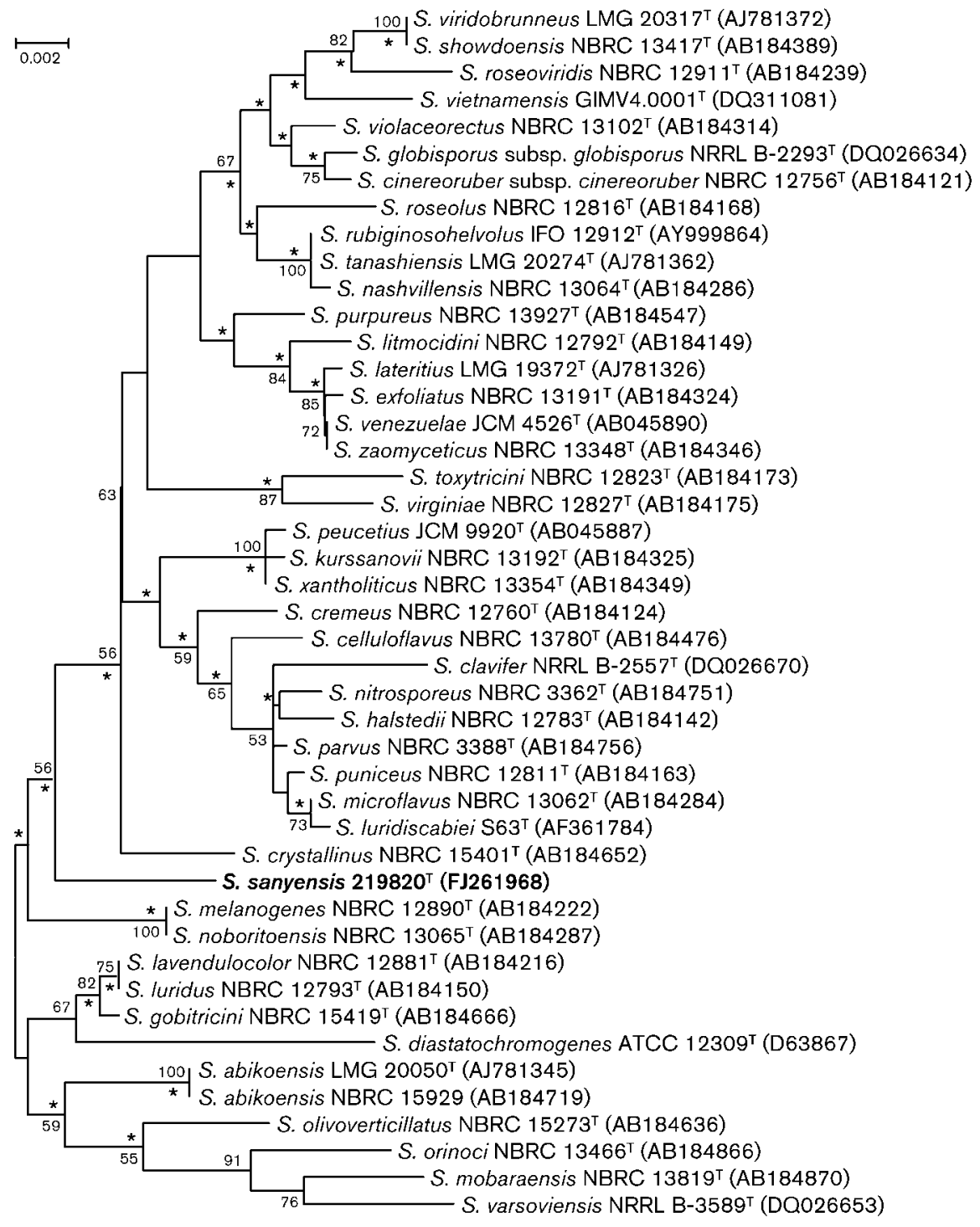

Fig. 2. Neighbour-joining phylogenetic tree, based on nearly complete $16 \mathrm{~S}$ rRNA gene sequences (1447 nt), showing the relationships between strain $219820^{\top}$ and strains of related species of the genus Streptomyces. Numbers at branching points indicate bootstrap percentages (based on 1000 replications); only values more than $50 \%$ are shown. Asterisks indicate branches of the tree that were also recovered using the maximum-parsimony tree-making algorithm. Bar, 0.002 substitutions per nucleotide position.

DNA-DNA hybridization tests were carried out between strain $219820^{\mathrm{T}}$ and the phylogenetically most closely related type strains. DNA-DNA relatedness values between strain $219820^{\mathrm{T}}$ and S. crystallinus NBRC $15401^{\mathrm{T}}(31.0 \pm$ $0.7 \%)$, S. melanogenes NBRC $12890^{\mathrm{T}}(27.8 \pm 0.9 \%)$ and $\mathrm{S}$. noboritoensis NBRC $13065^{\mathrm{T}}(17.5 \pm 0.5 \%)$ were all significantly lower than $70 \%$, the threshold value for the delineation of genomic species (Stackebrandt \& Goebel, 1994), thus suggesting that the novel strain should be considered as a representative of a separate species. Comparison of the phenotypic characteristics of strain $219820^{\mathrm{T}}$ and its closest phylogenetic neighbours also revealed significant differences (Table 1). S. crystallinus was selected for a detailed cultural characteristic comparison with strain $219820^{\mathrm{T}}$ on the basis of phylogenetic distance and DNA-DNA relatedness data and its close position to the novel isolate in the phylogenetic tree. The two strains could be easily differentiated based on cultural characteristics (Supplementary Table S1).

A combination of genotypic and phenotypic data show that strain $219820^{\mathrm{T}}$ merits recognition as the type strain of a novel species in the genus Streptomyces, for which the name Streptomyces sanyensis sp. nov. is proposed. 


\section{Description of Streptomyces sanyensis sp. nov.}

Streptomyces sanyensis (sa.ny.en'sis. N.L. masc. adj. sanyensis pertaining to Sanya, a coastal city in Hainan Province, where the mangrove sediment was collected from which the type strain was isolated).

Aerobic, Gram-positive actinomycete. Forms extensively branched substrate mycelium and aerial hyphae that differentiate into long Rectiflexibiles spore chains of up to 20 spores. Spores are elliptical or short rods with a smooth surface. Pale yellow to dark yellowish-brown colonies that carry white to grey aerial spore mass are formed on ISP media 1, 2, 3, 4 and 6, modified Bennett's agar, Czapek's agar and nutrient agar. No diffusible pigment is produced on any of the media tested. Melanin is produced on peptone-yeast extract-iron agar and tyrosine agar. Negative in tests for starch hydrolysis, nitrate reduction, L-tyrosine degradation, aesculin degradation and carboxymethyl-cellulose degradation; positive for gelatin liquefaction, milk coagulation and peptonization, $\mathrm{H}_{2} \mathrm{~S}$ production, urease production, catalase production, degradation of Tweens 20 and 80, growth on cellulose, and the oxidase test. Dextrin, glucose, mannose, maltose, glycerol, D-ribose and trehalose are utilized as sole carbon sources, but L-arabinose, D-fructose, D-galactose, myoinositol, inulin, lactose, D-mannitol, raffinose, L-rhamnose, salicin, sucrose and D-xylose are not. L-Alanine, D-arginine, L-asparagine, glycine, L-histidine, L-serine and L-ornithine are metabolized as sole nitrogen sources, but not L-cysteine, L-hydroxyproline, L-methionine, L-phenylalanine, L-proline or L-valine. Growth occurs at pH 5.0-9.0 (optimum, $\mathrm{pH} 7.0$ ), at $10-40{ }^{\circ} \mathrm{C}$ (optimum, $28{ }^{\circ} \mathrm{C}$ ) and with $0-10 \%($ w/v) $\mathrm{NaCl}$ (optimum, $0 \% \mathrm{NaCl}$ ). The cell wall contains LL-DAP with nearly the same amount of meso-DAP. Whole-cell hydrolysates contain galactose and glucose. Predominant menaquinones are $\mathrm{MK}-9\left(\mathrm{H}_{8}\right)$ and $\mathrm{MK}-9\left(\mathrm{H}_{6}\right)$. The diagnostic phospholipid is phosphatidylethanolamine. Major cellular fatty acids are iso- $\mathrm{C}_{16: 0}$, anteiso- $\mathrm{C}_{15: 0}$, iso- $\mathrm{C}_{15: 0}$, iso- $\mathrm{C}_{14: 0}$, 10-methyl $\mathrm{C}_{16: 0}, \mathrm{C}_{16: 1} \omega 9 c$ and summed feature $3\left(\mathrm{C}_{16: 1} \omega 7 c\right.$ and/or iso- $\left.\mathrm{C}_{15: 0} 2-\mathrm{OH}\right)$.

The type strain is $219820^{\mathrm{T}}\left(=\mathrm{CGMCC} 4.5626^{\mathrm{T}}=\mathrm{DSM}\right.$ $42014^{\mathrm{T}}$ ), isolated from a composite mangrove sediment sample collected in Sanya, Hainan Province, China, and exhibits cytotoxic activity against the human colon tumour cell line HCT-116. The G $+\mathrm{C}$ content of the genomic DNA of the type strain is $73.24 \mathrm{~mol} \%$.

\section{Acknowledgements}

This research was supported by grants of the National High Technology Research and Development Program of China (863 Program) (no. 2007AA09Z415), National Natural Science Foundation of China (no. U0633008), and National Nonprofit Institute Research Grant (ITBBZD0753).

\section{References}

Bérdy, J. (2005). Bioactive microbial metabolites. J Antibiot (Tokyo) 58, $1-26$.
Chun, J., Lee, J. H., Jung, Y., Kim, M., Kim, S., Kim, B. K. \& Lim, Y. W. (2007). EzTaxon: a web-based tool for the identification of prokaryotes based on $16 \mathrm{~S}$ ribosomal RNA gene sequences. Int J Syst Evol Microbiol 57, 2259-2261.

Dong, X.-Z. \& Cai, M.-Y. (editors) (2001). Determination of biochemical properties. In Manual for the Systematic Identification of General Bacteria, pp. 370-398. Beijing: Science Press (in chinese).

Felsenstein, J. (1985). Confidence limits on phylogenies: an approach using the bootstrap. Evolution 39, 783-791.

Fitch, W. M. (1971). Toward defining the course of evolution: minimum change for a specific tree topology. Syst Zool 20, 406-416.

Goodfellow, M., Kumar, Y., Labeda, D. P. \& Sembiring, L. (2007). The Streptomyces violaceusniger clade: a home for streptomycetes with rugose ornamented spores. Antonie van Leeuwenhoek 92, 173-199.

Hain, T., Ward-Rainey, N., Kroppenstedt, R. M., Stackebrandt, E. \& Rainey, F. A. (1997). Discrimination of Streptomyces albidoflavus strains based on the size and number of 16S-23S ribosomal DNA intergenic spacers. Int J Syst Bacteriol 47, 202-206.

Hasegawa, T., Takizawa, M. \& Tanida, S. (1983). A rapid analysis for chemical grouping of aerobic actinomycetes. J Gen Appl Microbiol 29, 319-322.

Hayakawa, M., Sadakata, T., Kajiura, T. \& Nonomura, H. (1991). New methods for the highly selective isolation of Micromonospora and Microbispora from soil. J Ferment Bioeng 72, 320-326.

Hayakawa, M., lino, H., Takeuchi, S. \& Yamazaki, T. (1997). Application of a method incorporating treatment with chloramine$\mathrm{T}$ for the selective isolation of Streptosporangiaceae from soil. J Ferment Bioeng 84, 599-602.

Hong, K., Gao, A. H., Xie, Q. Y., Gao, H., Zhuang, L., Lin, H. P., Yu, H. P., Li, J., Yao, X. S. \& other authors (2009). Actinomycetes for marine drug discovery isolated from mangrove soils and plants in China. Mar Drugs 7, 24-44.

Jones, K. L. (1949). Fresh isolates of actinomycetes in which the presence of sporogenous aerial mycelia is a fluctuating characteristic. J Bacteriol 57, 141-145.

Kämpfer, P., Kroppenstedt, R. M. \& Dott, W. (1991). A numerical classification of the genera Streptomyces and Streptoverticillium using miniaturized physiological tests. J Gen Microbiol 137, 1831-1891.

Kelly, K. L. (1964). Inter-Society Color Council - National Bureau of Standards Color Name Charts Illustrated with Centroid Colors. Washington, DC: US Government Printing Office.

Kimura, M. (1980). A simple method for estimating evolutionary rates of base substitutions through comparative studies of nucleotide sequences. J Mol Evol 16, 111-120.

Lechevalier, M. P. \& Lechevalier, H. A. (1980). The chemotaxonomy of actinomycetes. In Actinomycete Taxonomy, Special Publication no. 6, pp. 227-291. Edited by A. Dietz \& D. W. Thayer. Arlington, VA: Society for Industrial Microbiology.

Lechevalier, M. P., De Bièvre, C. \& Lechevalier, H. A. (1977). Chemotaxonomy of aerobic actinomycetes: phospholipid composition. Biochem Syst Ecol 5, 249-260.

Mesbah, M., Premachandran, U. \& Whitman, W. B. (1989). Precise measurement of the $\mathrm{G}+\mathrm{C}$ content of deoxyribonucleic acid by highperformance liquid chromatography. Int J Syst Bacteriol 39, 159-167.

Minnikin, D. E., O’Donnell, A. G., Goodfellow, M., Alderson, G., Athalye, M., Schaal, A. \& Parlett, J. K. (1984). An integrated procedure for the extraction of bacterial isoprenoid quinones and polar lipids. J Microbiol Methods 2, 233-241.

Oliver, J. D. \& Colwell, R. R. (1973). Extractable lipids of Gramnegative marine bacteria: fatty-acid composition. Int J Syst Bacteriol 23, 442-458. 
Pospiech, A. \& Neumann, B. (1995). A versatile quick-prep of genomic DNA from gram-positive bacteria. Trends Genet 11, 217218.

Saitou, N. \& Nei, M. (1987). The neighbor-joining method: a new method for reconstructing phylogenetic trees. Mol Biol Evol 4, 406425.

Sasser, M. (1990). Identification of bacteria by gas chromatography of cellular fatty acids, MIDI Technical Note 101. Newark, DE: MIDI Inc.

Shirling, E. B. \& Gottlieb, D. (1966). Methods for characterization of Streptomyces species. Int J Syst Bacteriol 16, 313-340.

Stackebrandt, E. \& Goebel, B. M. (1994). Taxonomic note: a place for DNA-DNA reassociation and $16 \mathrm{~S}$ rRNA sequence analysis in the present species definition in bacteriology. Int J Syst Bacteriol 44, 846849.
Tamura, K., Dudley, J., Nei, M. \& Kumar, S. (2007). MEGA4: molecular evolutionary genetics analysis (MEGA) software version 4.0. Mol Biol Evol 24, 1596-1599.

Waksman, S. A. \& Henrici, A. T. (1943). The nomenclature and classification of the actinomycetes. J Bacteriol 46, 337-341.

Wassill, L., Ludwig, W. \& Schleifer, K. H. (1998). Development of a modified subtraction hybridization technique and its application for the design of strain specific PCR systems for lactococci. FEMS Microbiol Lett 166, 63-70.

Wellington, E. M. H. \& Williams, S. T. (1978). Preservation of actinomycete inoculum in frozen glycerol. Microbios Lett 6, 151-157.

Williams, S. T., Goodfellow, M., Alderson, G., Wellington, E. M. H., Sneath, P. H. A. \& Sackin, M. J. (1983). Numerical classification of Streptomyces and related genera. J Gen Microbiol 129, 1743-1813. 